\title{
Antimicrobial Activity of Two Root Canal Filling Pastes in Deciduous Teeth: an in Vitro Study
}

\section{Avaliação "in vitro" da Atividade Antimicrobiana de Duas Pastas Obturadoras de Canais Radiculares de Dentes Decíduos}

\author{
Andréia Bolzan de Paula*; Janaina de Cássia Orlandi Sardib; Mariana Minatel ${ }^{\text {a }}$; Regina Maria Puppin-Rontanic \\ a'University of Campinas, Piracicaba Dental School, Restorative Dentistry Department, SP, Brazil \\ bUniversity of Campinas, Piracicaba Dental School, Department of Oral Diagnosis, Microbiology and Immunology, SP, Brazil \\ 'University of Campinas, Piracicaba Dental School, Pediatric Dentistry Department, SP, Brazil \\ *E-mail: andbol_63@hotmail.com \\ Received: February 2nd, 2014; Accepted: June 3rd, 2014
}

\begin{abstract}
Endodontic treatment in deciduous teeth is very important so that we can preserve the primary dentition and thus promote appropriate craniofacial development. However, the use of filling pastes that have some important biological properties for the preservation of the tooth is required. The objective this study was to evaluate the in vitro antimicrobial activity of two root canal filling pastes in deciduous teeth, Vitapex ${ }^{\circledR}$ and Calcipex ${ }^{\circledR}$, on microbial species commonly found in endodontic infections (Candida albicans, Enterococcus faecalis, Streptococcus mutans, Streptococcus sanguinis, Escherichia coli and Staphylococcus aureus), using the agar diffusion test. The experiment was carried out on BHI (Brain Heart Infusion) plates in four equidistant points, which were immediately filled with the sealers Vitapex ${ }^{\circledR}$ and Calcipex ${ }^{\circledR}$. The chlorhexidine gluconate $1 \%(\mathrm{CHX})$ and distilled water were used as positive and negative controls, respectively. After incubation of plates at $37^{\circ} \mathrm{C}$ for $24 \mathrm{~h}$, the diameter of the growth inhibition zones around the wells was measured (in millimeters) with a digital caliper with reflected light. The test was performed in triplicate and data were submitted to ANOVA and Tukey's test $(\alpha=0.05)$. Both pastes had antimicrobial activity, but Calcipex ${ }^{\circledR}$ was more efficient for most strains. The halo formed in the experiments with S. mutans and S. sanguinis was similar for both pastes. This study suggests that Calcipex ${ }^{\circledR}$ had the highest antimicrobial property with respect to the microorganisms studied.
\end{abstract}

Keywords: Bacteria. Fungi. Products with Antimicrobial Action.

\section{Resumo}

O tratamento endodôntico de dentes decíduos é de suma importância para que se possa preservar a dentição primária e, assim, promover desenvolvimento craniofacial adequado, oclusão normal e qualidades estéticas. No entanto, para que isso ocorra, é necessário o uso de pastas obturadoras com propriedades biológicas importantes para a preservação do dente. O objetivo deste estudo foi avaliar in vitro a atividade antimicrobiana de duas pastas obturadoras utilizadas em dentes decíduos, Vitapex ${ }^{\circledR}$ e Calcipex ${ }^{\circledR}$, em espécies microbianas comumente encontradas em infecções endodônticas (Candida albicans, Enterococcus faecalis, Streptococcus mutans, Streptococcus sanguinis, Escherichia coli e Staphylococcus aureus), utilizando o teste de difusão em ágar. Foram utilizadas placas de BHI (Brain Heart Infusion) e confeccionados quatro pontos equidistantes, imediatamente preenchidos com o Vitapex ${ }^{\circledR}$ cimentos e Calcipex ${ }^{\circledR}$. O gluconato de clorexidina a 1\% (CHX) e água destilada foram utilizados como controle positivo e negativo, respectivamente. Após a incubação das placas a $37{ }^{\circ} \mathrm{C}$ durante 24 h, o diâmetro das zonas de inibição do crescimento bacteriano ao redor dos poços foi medido (em milímetros) com um compasso de calibre digital com luz refletida. Este teste foi realizado em triplicata e os dados foram submetidos à análise de variância e teste de Tukey ( $\alpha=0,05)$. Ambas as pastas tiveram atividade antimicrobiana, mas Calcipex ${ }^{\circledR}$ foi mais eficiente para a maioria das cepas. $O$ halo formado nos experimentos contendo as cepas de S. mutans e S. sanguinis foi semelhante para ambas as pastas. No presente estudo, podemos sugerir que Calcipex ${ }^{\circledR}$ apresentou a melhor propriedade antimicrobiana em relação aos microrganismos estudados.

Palavras-chave: Bactérias. Fungos. Produtos com Ação Antimicrobiana.

\section{Introduction}

Despite the species of the endodontic microbiota are not pathogenic when analyzed separately, they may harmful when associated with some factors. Microbial interactions, as well as the selective pressures that occur because of reduced supply of oxygen and nutrients and deficient host defense can contribute to high pathogenicity of these microorganisms ${ }^{1}$. In these polymicrobial infections, the aerobic microorganisms are rare, most anaerobic and some are facultative anaerobes ${ }^{2}$. Fungi species have been found frequently in these infections ${ }^{2-4}$. Endodontic treatment of primary teeth is very important so that we can preserve the primary dentition and thereby promote proper craniofacial development, normal occlusion and aesthetic qualities ${ }^{5}$.

To ensure success in endodontic treatment, especially in primary teeth by their anatomical complications, only the instrumentation channel is not enough. It is necessary the use of filling pastes to gain access where a good mechanical preparation not possible ${ }^{6}$. To ensure good efficacy of obturation paste, some properties are required, such as to be proportional to the resorption of the tooth, be harmless to the periapical region and the permanent tooth germ, antiseptic, radiopaque, to easily fill out the canal, and adhere to the walls, be easily removed if necessary, and do not change the 
color of the tooth ${ }^{7-8}$.

There are several types of root canal obturation pastes on the market, including those pastes of calcium hydroxide. This component acts on tissues and bacteria by dissociation of calcium and hydroxyl ions. Hydroxyls can alter enzyme activity, inactivating it. Furthermore, enzymes act on the cytoplasmic membrane, thus having a wide field of action on microorganisms ${ }^{9}$.

However, to compare the variety of filling materials on the market, and to use an effective material in endodontic treatment, studies on the antimicrobial properties of materials are needed.

The aim of this study was to evaluate the in vitro antimicrobial activity of two root canal filling pastes in deciduous teeth, Vitape ${ }^{\circledR}$ and Calcipex ${ }^{\circledR}$ on six microbial species commonly found in endodontic infection.

\section{Material and Methods}

\subsection{Microorganisms}

Six standard microbial strains obtained from the American Type Culture Collection were used in this study, as follows: Candida albicans (ATCC 90028), Enterococcus faecalis (ATCC 10541), Streptococcus mutans (ATCC 25175), Escherichia coli (ATCC 10538), Staphylococcus aureus (ATCC 6538), and Streptococcus sanguinis (ATCC 10556). Prior to each experiment, the strains were aerobically cultured at $37{ }^{\circ} \mathrm{C}$ for $24 \mathrm{~h}$ on Brain Heart Infusion (BHI; Difco Laboratories, Detroit, MI, USA) and a loopful of microorganisms cultures growth was inoculated into Brain Heart Infusion (BHI) broth (Difco Laboratories, Detroit, MI, USA). After 18 to $20 \mathrm{~h}$ of incubation, cells were washed twice with PBS, suspended in BHI, and standardized to $10^{3}$ cells/ $\mathrm{mL}$, ascertained spectrophotometrically (Bausch \& Lomb Spectronic 20, San Pablo, Calif, USA) at $550 \mathrm{~nm}$.

\subsection{Root canal pastes}

The in vitro antimicrobial activity of the materials Vitapex ${ }^{\circledR}$ (Neo-Dental, Tokyo, Japan) and Calcipex ${ }^{\circledR}$ (Nippon Sika-Yakuhin, Shimonoseki, Japan) were evaluated by pour plate technique. Both $1 \%$ digluconate of chlorhexidine solution ( $\mathrm{CHX}$ ) and sterile water were used as positive and negative controls, respectively.

\subsection{Pour Plate technique and preparation of wells}

To pour plate technique, $1 \mathrm{ml}$ of the inoculum was transferred to a test tube containing $19 \mathrm{ml}$ of molten agar - BHI $\left(45^{\circ} \mathrm{C}\right)$, both were mixed and dispensed into sterile Petri dishes. After agar solidification, the wells were made at equidistant points using autoclaved metallic molds with $5 \mathrm{~mm}$ in diameter, a total of four wells per plate. Immediately after preparation of drilling, the wells were completely filled with folders and control obturation materials. The petri dishes were kept at room temperature for 2 hours to pre-diffusion of the substances occurs, and subsequently incubated at $37^{\circ} \mathrm{C}$ for 24 hours. After incubation, the diameter of zones of inhibition of microbial growth formed around the wells were measured in millimeters with a digital caliper (Mitutoyo, Tokyo, Japan) under reflected light. All results were analyzed statistically using Analysis of Variance and Turkey's test $(\alpha=0.05)$.

\section{Results and Discussion}

The results obtained by measuring the inhibition zones are shown in Table 1. Both pastes have inhibited all microorganisms. When analyzing the data, there was no statistical difference between the chlorhexidine (positive control) and Pasta II Calcipex for all microorganisms. While Vitapex showed the worst results, there was no statistical difference on positive control only for S. mutans and S. sanguinis microorganisms.

Table 1: Averages of inhibition zone ( $\mathrm{mm}$ ) of the material tested.

\begin{tabular}{lccc}
\hline & Vitapex $^{\circledR}$ & Calcipex ${ }^{\circledR}$ & Chlorhexidine \\
\hline S. mutans & $0.342^{\mathrm{A}}$ & $0.570^{\mathrm{A}}$ & $0.944^{\mathrm{A}}$ \\
S.sanguinis & $0.389^{\mathrm{A}}$ & $0.582^{\mathrm{A}}$ & $0.904^{\mathrm{A}}$ \\
C.albicans & $0.326^{\mathrm{B}}$ & $0.779^{\mathrm{A}}$ & $0.904^{\mathrm{A}}$ \\
E. faecalis & $0.382^{\mathrm{B}}$ & $0.665^{\mathrm{A}}$ & $0.718^{\mathrm{A}}$ \\
S. aureus & $0.407^{\mathrm{B}}$ & $0.683^{\mathrm{A}}$ & $0.688^{\mathrm{A}}$ \\
E.coli & $0.381^{\mathrm{B}}$ & $0.577^{\mathrm{A}}$ & $0.560^{\mathrm{A}}$
\end{tabular}

Upper case letters denote statistically equal not considering the data presented in rows $(\mathrm{p}<0.01)$.

The complete debridement of root canals of deciduous teeth is virtually impossible due to the anatomy of the root canal highly variable, so the success of endodontic therapy depends on the use of irrigants and filling material with antimicrobial activity ${ }^{10}$.

In the present study, the antimicrobial activity of two filling pastes based on calcium hydroxide was investigated: Vitapex, composed mainly of calcium hydroxide (30.3\%), Iodoform (40.4\%), and silicone oil (22.4\%), and II Calcipex consisting of calcium hydroxide (24\%), barium sulfate (24\%), and distilled water (52\%). Amorim et al. ${ }^{11}$ studied Vitapex and other 4 filling pastes for deciduous teeth (Guedes-Pinto, ZOE paste (zinc oxide eugenol), calcium hydroxide and ZOE + chloramphenicol + tetracycline) by agar diffusion tests and exposure to direct action. The authors found that the direct exposure test showed antimicrobial activity after 24 hours for all pastes. However, in the agar diffusion test, Vitapex showed no inhibition zone. Tchaou et al. ${ }^{12}$ used the agar diffusion method, and also found negative results for Vitapex, and classified the pastes into three groups: I- strong antimicrobial activity, II - intermediate action, and III-minimal or no action. Vitapex is framed in the third category, along with calcium hydroxide + sterile water and petrolatum (negative control). The calcium hydroxide-based paste used in this study 
(calcium hydroxide + camphorated Parachlorophenol) fitted into the category of strong antimicrobial activity. Blanscet et al. ${ }^{13}$ compared by the agar diffusion method the antimicrobial activity of five concentrations of calcium hydroxide, using three different vehicles: $60 \%, 50 \%$ and $40 \%$ calcium hydroxide in sterile saline solution, and the pastes Ultracal ( ) (35\% aqueous methylcellulose) and Vitapex ${ }^{\circledR}$. The most effective concentration was $60 \%$ calcium solution, followed by $50 \%$, but Ultracal $\AA$ (35\%) was more effective than $40 \%$ calcium solution, and Vitapex ${ }^{\circledR}$ showed the poorest results. Barcelos et al. ${ }^{14}$ performed a systematic review of filling materials for deciduous teeth, and found similar results for zinc oxide eugenol (ZOE), Vitapex and Sealapex. All cements had success in deciduous teeth with irreversible pulp alterations. In a study performed by Harina Prya et al. ${ }^{10}$, facultative/ Aerobic organisms were isolated in all cases, while anaerobic organisms were isolated in $80 \%$ cases, and Candida albicans was isolated in one case. ZOE showed higher inhibitory activity against most of the organisms, followed by Vitapex, calcium hydroxide, and Metapex in descending order.

Estrela et al. ${ }^{15}$ found a significant association of calcium hydroxide iodoform in relation to antimicrobial activity by agar diffusion method and direct exposure, and concluded that calcium hydroxide associated with saline showed the same activity as compared to that associated with iodoform and serum, while iodoform associated only with saline showed no antimicrobial activity. In a literature review conducted by Aydos and Milano ${ }^{16}$ on the use of iodoform, the authors concluded that this material does not have antimicrobial activity in vitro, but the results in vivo were divergent, suggesting the action of iodoform by stimulating biological body. The literature suggests that its action takes place by the release of iodine, but further studies are needed to clarify its action. Lima et al. ${ }^{17}$ compared the efficacy of $1 \%$ chlorhexidine gel, calcium hydroxide/camphorated paramonochlorophenol (Callen PMCC) against mutans streptococci and anaerobic bacteria found in primary molars with necrotic pulps. Chlorhexidine gel significantly reduced mutans streptococci levels, whereas Callen PMCC significantly reduced the levels of anaerobic bacteria. No differences in the reduction of mutans streptococci and anaerobes were observed between groups. Kriplani et al. ${ }^{18}$ evaluated the effectiveness of antimicrobial aloe Vera and in association with zinc oxide and eugenol, calcium hydroxide, and calcium hydroxide associated with aloe Vera against 18 bacteria strains isolated from infected root canals of primary molar teeth, using agar diffusion assay All materials showed antimicrobial activity against the bacteria. Aloe Vera and Sterile Water was found to have higher antimicrobial activity against most of the microorganisms, followed by ZOE and Aloe Vera, Aloe Vera and calcium hydroxide, ZOE, calcium hydroxide. Unlike the in vitro results, in vivo studies demonstrated good clinical performance of Vitapex. Nurko and Garcia-Godoy ${ }^{19}$ analyzed clinically the effectiveness of
Vitapex in the treatment of deciduous teeth, and according to the criteria used (tooth painlessly, without pathological mobility and healthy gums, and without fistulas) the authors reported high success rate. A similar result was found by Mortazavi and Mesbahi ${ }^{8}$, who compared Vitapex paste and ZOE, and even the calcium hydroxide based paste was more effective than ZOE. Another study on clinical and radiographic success of Vitapex as compared to 3Mix, found that 3Mix and Vitapex can be used as a root canal treatment agent in pulpally involved primary teeth. The authors suggested that this result may be due to the selected teeth presented a poor prognosis for treatment. In this research, both pastes have antimicrobial activity in vitro ${ }^{20}$.

No studies on the antibacterial action of Calcipex II are found in literature, but according to Estrela and Pesce ${ }^{21}$, one of the reasons for its higher efficiency when compared to Vitapex could be the hydro soluble vehicles (in the case of Calcipex II, distilled water), which can accelerate ionic dissociation and diffusion, and interfere with bacterial enzyme systems and tissue, thereby accelerating the activity of calcium hydroxide. In contrast, oily vehicles (found in Vitapex) may hamper the ionic dissociation of calcium hydroxide, hindering its antibacterial activity.

\section{Conclusion}

According to the experiments of this study, both pastes presented antimicrobial activity for all strains, and Calcipex II was more effective than the Vitapex.

\section{Reference}

1. Estrela C, Bammann LL, Pimenta FC, Pécora JD. Control of microorganisms in vitro by calcium hydroxide pastes. Int Endod J 2000;34:416-8.

2. Peciuliene V, Balciuniene I, Eriksen HM, Haapasalo M. Isolation of Enterococcus faecalis in previously root-filled canals in Lithuanian population. J Endod 2000;26:593-5.

3. Nair PNR, Sjogren U, Krey G, Kahnberg KE. Intraradicular bacteria and fungi in root-filled, asymptomatic human teeth with therapy-resistant periapical lesions: a long-term ight and electron microscopic follow-up study. J Endod 1990;16:580-8.

4. Sundqvist G, Figdor D, Persson S, Sjogren U. Microbiologic analysis of teeth with failed endodontic treatment and the outcome of conservative re-treatment. Oral Surg Oral Med Oral Pathol Oral Radiol Endod 1998;85:86-93.

5. Cox ST, Hembree JH, Mc Knight JP. The bactericidal potential of various endodontic materials for primary teeth. Oral Surg 1978;45:947-54.

6. Piva F, Faraco Júnior IM, Feldens CA, Estrela CRA. Antimicrobial action of root canal filling materials for primary teeth using the agar diffusion method: an In Vitro Study. Pesq Bras Odontoped Clin Integr 2009;9:13-7.

7. Rinfkin A. A simple effective safe technique for the root canal treatment of abscessed primary teeth. J Dent Child 1980;47:435-41.

8. Mortazavi M, Mesbahi M. Comparison of zinc oxide and eugenol, and Vitapex for root canal treatment of necrotic primary teeth. Int J Paed Dent 2004;14:417-24. 
9. Holland R, Otoboni-Filho JA, Souza V, Nery MJ, Bernabé PFE, Dezan-Jr E. Periapical tissue repair with diferents calcium hydroxide associations - study in dog' s teeth. Rev Ass Paul Cir Dent 1999;53:327-31.

10. Harini Priya M, Bhat SS, Sundeep Hegde K. Comparative evaluation of bactericidal potential of four root canal filling materials against microflora of infected non-vital primary teeth. J Clin Pediatr Dent 2010;35:23-9.

11. Amorim LF, Toledo OA, Estrela CR, Decurcio DA, Estrela C. Antimicrobial analysis of different root canal filling pastes used in pediatric dentistry by two experimental methods. Braz Dent J 2006;17:317-22.

12. Tchaou W, Turng B, Minah GE, Coll JA. In vitro inhibition of bacteria from root canals of primary teeth by various dental materials. Pediat Dent 1995; 17:351-5.

13. Blanscet ML, Tordik PA, Goodell GG. An agar diffusion comparison of the antimicrobial effect of calcium hydroxide at five different concentrations with three different vehicles. J Endod 2008;34:1246-8.

14. Barcelos R, Santos MP, Primo LG, Luiz RR, Maia LC ZOE paste pulpectomies outcome in primary teeth: a systematic review. J Clin Pediatr Dent 2011;35:241-8.

15. Estrela C, Holland R. Calcium Hydroxide: study based on scientific evidences. J Oral Appl Sci 2003;11:269-82.

16. Aydos JH, Milano NF. Revisão bibliográfica sobre o uso do Iodofórmio em Endodontia. Rev Fac Odontol Porto Alegre 1984;26:43-51.

17. Lima RA, Carvalho CB, Ribeiro TR. Fonteles CS. Antimicrobial efficacy of chlorhexidine and calcium hydroxide/camphorated paramonochlorophenol on infected primary molars: a split-mouth randomized clinical trial. Quintessence Int 2013;44:113-22.

18. Kriplani R, Thosar N, Baliga MS, Kulkarni P, Shah N, Yeluri R. Comparative evaluation of antimicrobial efficacy of various root canal filling materials along with aloevera used in primary teeth: a microbiological study. J Clin Pediatr Dent 2013;37:257-62.

19. Nurko C, Garcia-Godoy F. Evaluation of a calcium hydroxide/ iodoform paste $\left(\right.$ Vitapex $^{\circledR}$ ) in root canal therapy for primary teeth. J Clin Ped Dent 1999;23:289-94.

20. Nakornchai S, Banditsing P, Visetratana N. Clinical evaluation of 3Mix and Vitapex as treatment options for pulpally involved primary molars. Int J Paediatr Dent 2010;20:214-21.

21. Estrela C, Pesce HF. Chemical analysis of the liberation of calcium and hydroxyl ions from calcium hydroxide pastes in connective tissue in the dog Part I. Braz Dent J 1996;7:41-6. 